\title{
DEVIATION FROM TARGET CAPITAL STRUCTURE AS A FACTOR OF ACQUISITION DECISIONS IN EUROPEAN DEVELOPED MARKETS
}

The purpose of this paper is to examine the causal relation between deviations from target capital structure (leverage deficit) and acquisition choices in capital markets in Western Europe. The analysis is conducted using a sample of 921 large companies, which represents a strong and solid base for testing target capital structure and takeover interdependence, as the focus is on the period when half of the largest M\&A deals in Western Europe occurred. This study found that leverage deficit is a crucial determinant of acquisition choices and market reaction on acquisition announcements, measured by CARs to bidders. Companies that are underleveraged relative to their target capital structure have a higher probability of undertaking acquisitions. On the other hand, the market reacts unfavourably to acquisition announcements of underleveraged acquirers - overleveraged companies undertake the most value-enhancing acquisitions, whilst underleveraged companies make poor acquisition choices. This paper enriches the literature by empirically extending the understanding of how managers make investment decisions in relation to capital structure, and how capital markets assess the impact of these investments.

Keywords: capital structure, acquisitions, leverage deficit, Western Europe, capital market, cumulative abnormal returns.

JEL Classification: G10, G14, G15, G30, G32, G34

DOI: $10.15611 /$ aoe.2021.1.03

\section{INTRODUCTION}

This paper aims to fill the gap in the analysis of shaping capital structure in relation to M\&A, by enriching the existing research with the leverage deficit concept, and estimating the effects of management investment decisions in European capital markets.

Corporate restructuring through acquisitions represents the primary way in which companies may increase business value and provide returns to their shareholders. Being the largest investment decisions that companies can make, acquisitions are very complex transactions which require both decision-

\footnotetext{
* Faculty of Economics, Department of Finance, University of Montenegro, Montenegro.
} 
making on strategy choice and sources of finance. Numerous studies (Andrade et al., 2001; Eckbo, 2009; Martynova and Renneboog, 2009; Hu and Yang, 2016) have highlighted the strong relation between capital structure (sources of finance) and corporate takeovers. Even though these topics have been examined over the years, there are only a few academic papers that analysed target capital structure as a factor of the acquisition decision-making process (Maloney et al., 1993; Harford et al., 1999; Uysal, 2007, 2011; Harford, 2009). It is important to point out that Uysal $(2007,2011)$ gave the first results on the effect of leverage deficit (the deviation from target debt or leverage) on acquisition decisions and no similar research has been conducted after 2011 (to the best of this author's knowledge). The paper represents one of the most cited and influential articles in the field of M\&A and target capital structure interdependence.

To sum up, there is an evident lack of such research in developed countries of Western Europe, with only a few research papers analysing the relation between target capital structure and acquisition choices, and only one which gives the results on the actual impact of leverage deficit on acquisition decisions. The optimal choice of the financial resources mix has become one of the most crucial scientific dilemmas, overcoming its basic function of debt and equity choice. The issue of optimal capital structure has been the focus of numerous financial studies, yet it still remains unresolved.

Considering these facts, this paper aims to shed light on the causal relation between the leverage deficit of the bidder and the resulting acquisition choices made accordingly, as well as to test the market reaction, measured by changes in the bidders' stock price in Western Europe. The analysis focuses on the period of 2003-2010, which incorporates the sixth M\&A cycle. Even though it is important to have an up-to-date sample, the relevant research regarding M\&A consists of the periods with important changes in M\&A transactions seven of the ten largest M\&A deals worldwide were completed from 1998 to 2007, and five of the ten largest M\&A deals in Western Europe were completed in 2003-2010 ${ }^{1}$. Consequently, this sample represents a strong and solid base for the estimation of target capital structure. Additionally, it is also extremely important to analyse previous periods, in order to understand the causes of the current results in the M\&A segment.

This paper tests two research questions/hypotheses:

1. Is leverage deficit a significant factor in the process of acquisition choices (are underleveraged companies more acquisitive)?

\footnotetext{
${ }^{1}$ Bloomberg database and Institute for Mergers, Acquisitions and Alliances, IMAA; https:// imaa-institute.org/mergers-and-acquisitions-statistics/
} 
2. How do capital markets react to the acquisition announcements of underleveraged companies?

The research is based on prior analysis conducted by Uysal $(2007,2011)$. The first part of the analysis tested the probability of acquisition depending on the acquirers' leverage deficit. In the second part, the market reaction to the acquirers' announcements was tested, calculating the cumulative abnormal returns to bidders over a five-day event window. The sample consists of 921 large bidders, which gives the possibility to precisely test debt ratios, as large companies are prone to significant changes in capital structure, especially during corporate takeovers. Compared to previous research (Mugoša, 2015), this study used the estimation of capital structure determinants as a crucial factor to determine leverage deficit and to generate a completely new and more complex methodology and analysis - to test the probability of making an acquisition depending on the deviations from target debt ratio, and the capital market's reactions to these announcements.

The contribution of this paper is in the estimation of the target capital structure and investment decisions' interdependence in the developed European markets, which has not been researched as much as North American market, specifically in the context of fluctuations in actual debt ratio (leverage deficit). Furthermore, mergers and acquisitions are a vital part of today's global economy across various industries. This is the reason why these transactions are very interesting to focus on in research. Additionally, detailed and comprehensive data generated from acquisitions createsthe opportunity to conduct objective and in-depth analysis. The empirical verification of the model could be of use for managers in the process of evidence-based capital structure decision-making, by facilitating the decision as to what are the most important factors of optimal capital structure, and how this structure can accordingly impact on future investment decisions. Finally, the results of this research could be used in order to make a comparison with the US research (to test the differences between these two markets), taking into account the global investments of multinational companies, as well as to call for this analysis in Central and Eastern Europe.

The reminder of the paper is organized as follows: Section 2 presents the relevant theoretical and empirical evidence concerning capital structure and corporate restructuring. Section 3 describes the used methodology (FGLS target debt estimation, probability analysis, event study). Section 4 generates the results and discussion. Section 5 provides the final conclusion and direction for future research. 


\section{THEORETICAL BACKGROUND}

Starting from Miller and Modigliani (1958) and the irrelevance proposition, capital structure research has been continuously conducted over five decades, leading to the formulation of contemporaneous models and theories. The central theme analysed in the literature is the possibility of capital structure optimization. A comprehensive model which incorporates all empirical observations does not exist, therefore each company must develop financial flexibility and set targets under imposed specific conditions (Myers, 1984).

Empirical research suggests that the real situation on the market is reflected in the mix of different theories (Graham and Harvey, 2001; Bancel and Mittoo, 2004; Brounen et al., 2006). Testing the application of capital structure theoretical concepts showed that companies, especially large ones, define target debt ratio, ranging from strict or somewhat strict to flexible. On the other hand, the main factors affecting capital structure decisions are financial flexibility (preserving unused debt capacity) and credit rating. This means that depending on financial flexibility, transactions, agency and financial distress costs, companies tend to adjust their target capital structure (Kayhan and Titman, 2007). The results lead to the conclusion that empirical evidence is not in favour of any single theory. Still, it is important to notice that the finance theory is more applicable regarding larger companies and that the majority of companies have target debt ratios.

Various studies (Hovakimian et al., 2001; Fama and French, 2002; Leary and Roberts, 2005; Kayhan and Titman, 2007; Uysal, 2007, 2011; Harford et al., 2009; Hernádi and Ormos, 2012; Tao et al., 2017) found that companies adjust capital structure and move towards target debt ratios, specifically due to different corporate activities. Bearing in mind that capital structure is an important factor in determining if a company becomes a target or bidder, adjusting capital structure can be used as a financial motive prior to, and post M\&A transaction. The findings from Yang (2011) suggest that companies approach their target leverage ratios when acquiring other firms. Vermaelen and $\mathrm{Xu}(2014)$ state that acquirers in $80 \%$ of cases move toward target debt ratios and that the payment made in cash, which is mostly used by underleveraged bidders, is common compared to equity financing. Bidders have significantly lower leverage ratios, while in the meantime a larger financial slack, prior to acquisitions. Accordingly, cash-rich bidders are more likely to acquire a slack-poor target, due to the greater access and availability of financial sources (unused debt capacity). Leary and Roberts (2005) also confirm adjustments toward an optimal range of capital structure, due to possible profitable investments, whereas it is important to increase financial 
flexibility. Higher financial flexibility definitely goes along with lower leverage, which is essential to acquirers when deciding to enter in the process of M\&A (Bouraoui and Li, 2014).

Uysal $(2007,2011)$ specifically emphasizes the importance of the link between the deviations from target capital structure or leverage deficit and corporate investments. The current capital structure may impact on future investment opportunities or M\&A, especially when financial flexibility varies depending on present market frictions (Baker and Martin, 2011). Constrained financial flexibility leads to a deviation from target debt ratio, which consequently may determine the possibility of the company to engage in M\&A activities, as well as define its position in these transactions - being a bidder or a target. This is why a deviation from the target capital structure plays an important role in corporate investment decisions. For example, an overleveraged company will probably be unable to perform a takeover, being a cash-poor firm, and in this situation it is forced to use equity financing, which is the costliest source of financing. These companies are less likely to engage in M\&A activities, compared to underleveraged or cash-rich firms. Accordingly, the results from Uysal's (2007) research suggest that underleveraged companies are more acquisitive (one standard deviation decrease in leverage deficit increases the likelihood of making an acquisition by $7.4 \%$ ). Underleveraged companies have higher financial flexibility and more financing sources available. The author also concluded that underleveraged bidders acquire larger targets and engage in the process of acquisition more frequently.

However, a challenging and very important question in this context is, what are the valuation effects on capital markets when considering the capital structure's impact on M\&A transactions (bidder's performance)? M\&A's basic goal is to produce positive effects and increase the value of a new company through synergy. Due to market imperfections, these transactions will be assessed according to the chosen financial mix, with respect to the agency costs. It must be taken into account that stock prices play an important role in determining capital structure, especially if the company considers issuing equity. This is why changes in stock prices must be considered in order to test the success of transaction. M\&A valuations are mostly estimated using an event study, measuring the cumulative abnormal returns of acquirers around the event of takeover. Uysal $(2007,2011)$ indicated that stock prices decrease in cases of acquisition announcements of underleveraged companies. This result is consistent with Jensen's (1986) free cash flow hypothesis, which states that cash-rich firms may make negative investment choices that benefit them personally, namely the increase of free cash flow agency costs. Various 
studies focused on the impact of leverage on the returns of both the bidder and the target. Maloney, McCormick and Mitchell (1993) reported higher acquisition returns with the greater increase in bidders'leverage. Smith and Kim (1994) found that the average returns of bidders with high free cash flows are negative, which leads to inefficient NPV choices (paying too much for a target). This means that slack-poor bidders (higher leverage) have higher positive total returns. As the authors stated, restraining management by decreasing liquidity and increasing leverage in companies with high free cash flows, will increase the shares' value. Consistent with the arguments of Jensen (1986), Kang (1993) reported that the returns of Japanese bidders when they acquire US targets, increase with the bidders' total debt (additionally, the ties to financial institutions and the depreciation of the dollar had a positive effect on the bidder's returns). The research most closely related to Uysal's paper, conducted by Harford (1999), also resulted in a negative market reaction to acquisition announcements of cash-rich firms, whereas cash-richness was a strong predictor of the acquisition likelihood. The evidence from this paper was consistent with the explanatory power of the free cash flow hypothesis. Yet Harford did not apply deviations from target capital structure as a factor, but focused on the deviation of a firm's cash reserves from its predicted optimal level. Harford, Klasa and Walcott (2009) implemented deviations from the target capital structure, and their evidence is in line with the previously considered abnormal returns, as well as with the trade-off theory, as bidders rebalance capital structure towards the target after the takeover. The more recent paper by Beschwitz (2018) concluded that cash windfalls cause the decrease of abnormal returns to bidders (overinvestment). These results are consistent with the view that high leverage can be used as a disciplinary mechanism that will decrease agency costs and problems between managers and shareholders.

The general conclusion is that leverage plays an important role in the process of acquisition choices and outcomes. Lower leverage means the higher probability of acquisitions, while increased leverage is associated with higher abnormal returns, indicating that managers have made investments which increase shareholders' value (Durand et al., 2016; Uysal, 2007, 2011; Ahmed and Elshandidy, 2018). Finally, the leverage deficit can be used as an efficient and significant determinant, because it subsumes the effects of both excess cash reserves and leverage. The importance of leverage as a factor of investment decisions was also confirmed in the paper by Harford and Uysal (2014), which broadened the analysis to the impact of debt market access on the ability to make investments. The results suggest that constrained access to debt leads to underinvestment. 
The findings of this paper aim to solve the research gap found in the relation between the deviations from the target capital structure and M\&A in Western European capital markets.

\subsection{Determinants of target debt ratio}

In order to estimate the effects of leverage deficit on acquisition choices, target debt ratio is regressed on a set of potential determinants of capital structure, used in previous studies (Rajan and Zingales, 1995; Hovakimian et al., 2001; Uysal, 2007). The determinants will include proxies for tangibility (tangible assets ratio), growth, size, profitability and product uniqueness. The first four determinants are included in the core model of leverage (Frank and Goyal, 2009), a model which consists of the most important capital structure factors. The reasoning behind this model is the fact that these variables/factors explain over $30 \%$ of variations in leverage. The results from previous studies show that tangibility, growth, size and profitability are constantly applied in models, whereas other factors vary depending on the specific research (expected inflation, tax rates, product uniqueness, cash flow volatility etc.).

Tangibility of assets represents an important capital structure determinant, as companies with a higher share of tangible assets are likely to have higher leverage. Tangible assets as collateral provide better access to creditors, lower bankruptcy and financial distress costs. When the debt issued is secured by the property with known values (liquid assets), these firms are more likely to have lower bankruptcy and agency costs, and hence higher target debt ratios (Titman and Wessels, 1998; Uysal, 2007). On the other hand, if the structure of debt is being considered (short-term debt), the specific industry of the company (illiquid assets), tightened banks' credit activity and the illiquid capital market, collateral can be negatively related to target debt ratio. In this study, the ratio of tangible assets to the book value of total assets will be used as a proxy for tangibility.

Company's growth affects capital structure. High level of leverage could potentially limit growth and prevent future profitable investment. The costs associated with the agency conflict are particularly higher for growing firms and industries (Titman and Wessels, 1998; Uysal, 2007; Kirch et al., 2012). Accordingly, it can be assumed that growth opportunities will be negatively related to target debt. 'Market to Book' (ratio of company's market value to its total assets) and 'Total Return' (average stock price return) were used as proxies for growth (Uysal, 2007). Changes in stock prices can significantly impact capital structure as they serve as a proxy of the company's market performance. Sudden increases in stock prices (stock run-ups) cause shares issuance, 
implying a negative relation between stock returns and debt (Hovakimian et al., 2001; Baker and Wurgler, 2002; Welch, 2004; Uysal, 2007). Stock return is defined as the average adjusted percentage annual stock return.

Size represents another important factor of capital structure. Large companies have less volatile cash flows, lower bankruptcy and financial distress costs, and easier access to sources of financing (Rajan and Zingales, 1995; Uysal, 2007, 2011; Frank and Goyal, 2009; Kirch et al., 2012). Easier access to creditors is gained through the more transparent and diversified business of these companies, compared to small ones, which decreases information asymmetry and agency costs (large companies' shares are often traded in the stock market). This implies a positive correlation between size and target leverage. The impact of size determinant is proxied by the natural logarithm of sales.

Profitability is assumed to be positively correlated to debt, as more profitable firms are less prone to bankruptcy (Frank and Goyal, 2009). On the other hand, firms prefer internal over external funds (according to the peckingorder theory) and this fact suggests a negative relation between profitability and target debt ratio (Kędzior, 2012). Profitability will be proxied by earnings before taxes, preferred dividends and interest payments over total assets.

Product uniqueness is a measure of the unique and specific business (production, distribution). Unique products require higher costs of production and trade, leading potentially to higher costs of bankruptcy and financial distress (Titman and Wessels, 1998). Consequently, access to creditors is limited, decreasing target leverage ratio. Thus it is assumed that uniqueness and leverage are negatively correlated. The proxy for this determinant will be the ratio of research and development (R\&D) expenditure to total assets.

\section{METHODOLOGY}

\subsection{Sample selection}

The estimation of target leverage ratio was conducted through the analysis of the annual panel data of companies in Western Europe covering the period from 2003 to 2010. As mentioned in the introduction, this sample represents a solid base for the analysis of target capital structure, as the majority of the largest M\&A deals in Western Europe were completed in that period. The data was generated from Bloomberg Annual Files. Companies which met the following criteria were included in the sample:

1. actively trading stocks in observation period;

2. companies domiciled in Western Europe; 
3. companies not operating within the financial sector and regulated utilities;

4. types of securities traded are common stocks;

5. the value of sales in the fiscal year 2010 was greater than or equal to 50 million euros;

6. market capitalization in the fiscal year 2010 was greater than or equal to 400 million euros ${ }^{3}$.

After meeting these criteria, the sample created consisted of 921 large companies that were engaged in acquisition activities. Large companies provide the possibility to precisely test debt ratios, as they are prone to significant changes in capital structure especially during corporate restructuring. Target leverage ratio was estimated by testing following fundamental capital structure indicators/determinants:

1. Book leverage (BL) defined as Total Liabilities over Total Assets.

2. Tangibility (TA) defined as Tangible Assets over Total Assets.

3. Market to Book (MB) defined as Total Market Value over Total Assets.

4. Sales are the natural logarithm of Sales, Revenue or Turnover.

5. Profitability defined as EBITDA over Total Assets.

6. Product Uniqueness (PU) defined as R \& D Expenditures over Total Assets.

7. Total Return /average stock returns (TR).

\subsection{Target debt ratio estimation procedure}

Previously conducted empirical research suggests that companies have targets related to debt ratio. US evidence shows (Graham and Harvey, 2001) that the target exists as strict (10\%), somewhat tight (37\%) and flexible (37\%). In Europe, approximately $75 \%$ of companies have somewhat tight to flexible target debt ratios (Bancel and Mittoo, 2004; Brounen et al., 2006). Accordingly, the adjustments and deviations from target debt ratios can be explained by various theoretical reasons: information asymmetry, market timing, free cash flow etc. Consistent with empirical research and capital structure theoretical concepts,

\footnotetext{
${ }^{2}$ Based on the rules adopted by the European Commission in 2005, still in force, a company is defined as small and medium sized (SME) if its annual income from sales is less than or equal to 50 million euros.

${ }^{3}$ Even though there is no consensus on a lower and upper market capitalization limit, this value for SMEs in Western Europe ranged, on average, from 100 to 200 million euros, while in 2010 it amounted to 400 million euros on average. These companies were excluded from the sample for two reasons: (1) to focus on financially stable companies, which are most probably large companies; (2) a negligible proportion of small companies would, through extreme values in the model, create the effect of noise (noisy variables).
} 
in the first phase the target or optimal leverage ratio is estimated by regression of book leverage of company $i$ on a vector of explanatory variables:

$$
\begin{gathered}
\text { Book leverage }_{i}=\alpha+\beta_{1} \frac{\text { Tangible Assets }_{i}}{\text { Total Assets }_{i}}+\beta_{2} \text { Market to Book }_{i}+\beta_{3} \text { LogSales }_{i}+\ldots \\
+\beta_{4} \frac{\text { Ebitda }_{i}}{\text { Total Assets }_{i}}+\beta_{5} \frac{R \& D_{i}}{\text { Total Assets }_{i}}+\beta_{6} \text { AverageStock Return }_{i}+\varepsilon_{i} .
\end{gathered}
$$

The model includes book leverage as a dependent variable. First, there is a mechanical relationship between market leverage and the determinants expressed in market values (e.g. market to book). If market value increases, spurious correlation can occur between the variables scaled by market value, increasing both the left and the right side of regression (Parsons and Titman, 2009). Additionally, due to steep run-ups of stock prices, market leverage regression results can lead to confusing results, meaning that some firms could be potentially identified as underleveraged. Finally, studies show that the book value of leverage proved to be suitable in testing assumptions of capital structure theories (Fama and French, 2002).

In order to capture and control the effects of the time-invariant characteristics of unobservable firm-specific factors, the model was primarily estimated with the Fixed-Effects Panel Method (FE). The time-invariant characteristics of unobservable firm-specific factors explain most of the cross-sectional variations in capital structure and the potential deviation from the target capital structure. These characteristics are the company's sector of activity, managerial skills, managerial abilities etc. Recent empirical evidence (Flannery and Rangan, 2006; Lemmon et al., 2008; Chang and Dasgupta, 2011), shed some light on the reliability of OLS and the Tobit regression and the explanatory power of capital structure determinants, as these methods estimates may be biased because of their not controlling for omitted variables (unobservable firm-specific factors). However, the results of FE were subject to bias, because FE post-estimation indicated the presence of heteroskedasticity and first-order autocorrelation. This was the reason to apply the Feasible Generalized Least Squares Method (FGLS). FGLS allows estimation in the presence of AR(1) autocorrelation within panels and cross-sectional correlation and heteroskedasticity across panels. Being based on the calculation of panelspecific residual variance structure, FGLS could potentially absorb the fixed effects for the panel variable specified. FGLS is defined as (Baltagi, 2013):

$$
\beta_{F G L S}=\left(X^{\prime} \Omega X\right)^{-1} X^{\prime} \Omega y,
$$

where: $X$ represents independent variable, $Y$ dependent variable and $\Omega$ covariance matrix of unique errors. 


\subsection{Univariate analysis and multivariate analysis - probit}

This stage of the analysis gave the answer to the first research hypothesis: is capital structure a significant factor in the acquisition process, and if confirmed, are underleveraged companies more acquisitive? The probability of making an acquisition was tested by univariate and multivariate (probit) analysis.

Univariate analysis is a simple form of statistical analysis, which describes the frequency and distribution of the data. Multivariate models or binary choice models are applied in cases of a binary dependent variable - a variable taking the value 0 or 1 . The probability of the dependent variable taking one of two values is estimated using the probit or logit model (Wooldridge, 2012).

$$
\lim _{\beta^{\prime} x \rightarrow+\infty} \operatorname{Prob}(\gamma=1)=1 \text { and } \lim _{\beta^{\prime} x \rightarrow-\infty} \operatorname{Prob}(\gamma=1)=0 .
$$

The probit model is defined as:

$$
\operatorname{Prob}(\mathrm{Y}=1)=\int_{-\infty}^{\beta^{\prime} \mathrm{x}} \frac{1}{\sqrt{2 \pi}} \exp \left[-\left(\mathrm{t}^{2} / 2\right)\right] \mathrm{dt}=\int_{-\infty}^{\beta^{\prime} x} \phi(\mathrm{t}) \mathrm{dt}=\phi\left(\beta^{\prime} \mathrm{x}\right)
$$

where: $\phi(t)$ is standard normal density, and $\phi$ is standard normal cumulative distribution.

Cumulative distribution function for a discrete variable is given by:

$$
\mathrm{F}(\mathrm{a})=\mathrm{P}(\mathrm{x} \leq \mathrm{a}) \text {, whereas } 0 \leq \mathrm{F}(\mathrm{a}) \leq 1 .
$$

The function is non-decreasing and probability distribution is computed as:

$$
F(a)=\sum_{x_{i} \leq a} p_{i} .
$$

\subsection{Market valuation of M\&A - event study}

Event studies are used to assess the impact of an event (M\&A, stock split, earnings and dividends announcements) on the value of a company and its stock price. The aim of an event study is to determine whether, due to a certain event, there exists an abnormal stock price performance or abnormal return, in the analysed period of time, i.e. an event window. If the market is efficient, the effects of the event will be immediately reflected in stock price changes. In this manner, in a relatively short period it is possible to observe the significant economic impact of the event which occurred. The event study was first applied by Fama et al. (1969), to test the market efficiency or the adjustment speed of stock prices to stock splits announcements. The authors 
used the market model to assess abnormal returns, now one of the most common models used. In the first step the expected return on stock $i$ in month $t, E\left(R_{i t}\right)$ is calculated using a benchmark, stock market index $R_{m t}$ :

$$
E\left(R_{i t}\right)=\alpha+\beta_{i} R_{m t}+u_{i t}
$$

In the second step, the abnormal return $A R_{i t}$ is derived as the difference between the actual stock return $\mathrm{R}_{\mathrm{it}}$ and the expected stock return $E\left(R_{i t}\right)$ :

$$
A R_{i t}=R_{i t}-E\left(R_{i t}\right)
$$

Accordingly, one generates average abnormal returns $A R_{t}$ for each company $i$ in period $t$ ( $N$ represents the number of companies):

$$
\overline{A R}_{t}=\frac{1}{N} \sum_{i=1}^{N} A r_{i t}
$$

Finally, in the third stage the average abnormal returns are added up in order to obtain cumulative abnormal returns, or the information cumulative effect on the stock prices. The information effect is measured in period $t_{1}-t_{2}$ (the days before and after announcement day $t_{0}$ ):

$$
\overline{C A R}_{t_{1}, t_{2}}=\sum_{t=t_{1}}^{t_{2}} \overline{A R}_{t}
$$

The final step is the test of abnormal and cumulative abnormal returns of statistical significance, using the ordinary least square method. In this context the results of the event study give the answer to the second research hypothesis related to the market reaction on the acquisitions announcements.

\section{RESULTS AND DISCUSSION}

\subsection{Descriptive statistics}

The first results are given through the summary statistics of companies from the sample as shown in Table 1.

The book leverage on average amounts to 0.599 with a high standard deviation of 0.205 . The large variance around the mean could imply that a group of companies potentially deviate from the target debt ratio. Potentially, one could presume that, according to these changes, the sample consists of 
Table 1

Summary statistics of 921 companies from 2003-2010

\begin{tabular}{l|c|c|c|c|c|c|c}
\hline \multicolumn{1}{c|}{ Value } & BL & TA & MB & $\begin{array}{c}\text { Log } \\
\text { Sales }\end{array}$ & Profitability & PU & TR \\
\hline Number of companies & 921 & 921 & 921 & 921 & 921 & 921 & 921 \\
\hline $\begin{array}{l}\text { Number of company's } \\
\text { yearly observations }\end{array}$ & 7048 & 7048 & 7048 & 7034 & 7048 & 7048 & 6508 \\
\hline Average & 0.599 & 0.755 & 1.378 & 9.229 & 0.145 & 0.020 & 26.526 \\
\hline Median & 0.604 & 0.832 & 1.072 & 9.192 & 0.128 & 0.000 & 21.404 \\
\hline Standard deviation & 0.205 & 0.251 & 1.635 & 0.687 & 0.137 & 0.057 & 61.771 \\
\hline Variance & 0.042 & 0.063 & 2.674 & 0.472 & 0.019 & 0.003 & 3815.652 \\
\hline Coefficient of variation & 0.342 & 0.332 & 1.187 & 0.074 & 0.945 & 2.856 & 2.329 \\
\hline Q1 & 0.485 & 0.650 & 0.748 & 8.776 & 0.092 & 0.000 & -4.724 \\
\hline Q3 & 0.713 & 0.944 & 1.603 & 9.698 & 0.179 & 0.020 & 49.348 \\
\hline Interquartile difference & 0.228 & 0.295 & 0.855 & 0.922 & 0.087 & 0.020 & 54.072 \\
\hline
\end{tabular}

Source: author's calculations.

companies being underleveraged or overleveraged. The mean values of explanatory variables TA, MB, Log Sales, Profitability, PU and TR are 0.755 , $1.378,9.229,0.145,0.020$ and 26.526 , respectively.

\subsection{Target leverage ratio estimation}

In the first phase, FGLS is applied in the target leverage ratio estimation procedure. The FGLS estimator could inflate the chi-square statistic if the dummy variables for firm-specific factors are included. Therefore, two models were estimated: Model 1 without dummy variables and Model 2 including industry and time dummies (controlling for industry effect and macroeconomic changes over the years). Table 2 summarizes the results of the coefficient estimates of the yearly target leverage ratio regressions.

The results are similar in Model 1 and Model 2: each determinant is statistically significant in terms of sign and correlation to target debt ratio. Even though the inclusion of dummies did not significantly impact on the coefficient results, it did inflate the chi-square statistics (varying from 843.33 in Model 1 to 3596.43 in Model 2). Therefore Model 1 was used as the further basis for leverage deficit's impact estimation. 
Table 2

Regression estimates of the target leverage ratio using FGLS

\begin{tabular}{|c|c|c|}
\hline Variables & $F G L S(1)$ & $F G L S(2)$ \\
\hline Tangibility & $\begin{array}{c}-0.0143 * * * \\
(0.00330)\end{array}$ & $\begin{array}{c}-0.00910^{* *} \\
(0.00362)\end{array}$ \\
\hline Market to Book & $\begin{array}{c}-0.00941 * * * \\
(0.00114) \\
\end{array}$ & $\begin{array}{c}-0.00426^{* * *} \\
(0.00100)\end{array}$ \\
\hline Logarithm of sales & $\begin{array}{l}0.0657 * * * \\
(0.00301)\end{array}$ & $\begin{array}{l}0.0702 * * * \\
(0.00311)\end{array}$ \\
\hline Profitability & $\begin{array}{c}-0.0759 * * * \\
(0.00874)\end{array}$ & $\begin{array}{c}-0.0749 * * * \\
(0.00866) \\
\end{array}$ \\
\hline Product uniqueness & $\begin{array}{c}-0.0875^{* * *} \\
(0.0226)\end{array}$ & $\begin{array}{c}-0.0593 * * * \\
(0.0191)\end{array}$ \\
\hline Total return & $\begin{array}{c}-6.25 \mathrm{e}-05^{* * *} \\
(1.02 \mathrm{e}-05) \\
\end{array}$ & $\begin{array}{c}-2.86 \mathrm{e}-05^{* *} \\
(1.15 \mathrm{e}-05) \\
\end{array}$ \\
\hline Constant & $\begin{array}{c}0.0239 \\
(0.0287) \\
\end{array}$ & $\begin{array}{l}-0.0242 \\
(0.0294) \\
\end{array}$ \\
\hline Number of observations & 6,482 & 6,482 \\
\hline Number of variables & 879 & 879 \\
\hline Panels & Heteroskedastic & Heteroskedastic \\
\hline Correlation & $\begin{array}{c}\text { Common AR(1) coefficient } \\
\text { for all panels }(0.7888)\end{array}$ & $\begin{array}{c}\text { Common AR(1) coefficient } \\
\text { for all panels }(0.7471)\end{array}$ \\
\hline Estimated covariances & 879 & 879 \\
\hline Estimated autocorrelations & 1 & 1 \\
\hline Wald $\chi^{2}(6)$ & 843.33 & 3596.43 \\
\hline Prob $>\chi^{2}$ & 0.0000 & 0.0000 \\
\hline
\end{tabular}

Note: Standard errors in parentheses. ${ }^{* * *} \mathrm{p}<0.01,{ }^{* *} \mathrm{p}<0.05,{ }^{*} \mathrm{p}<0.1 /$

Source: author's calculations.

The results of the coefficient estimates are largely consistent with those of previous studies (Hovakimian et al., 2001; Kayhan and Titman, 2007; Uysal, 2007, 2011; Frank and Goyal, 2009; Hernádi and Ormos, 2012; Kirch et al., 2012). Target debt ratio increases with sales $(0.0657$, p-value less than 0.001$)$. Presumably, larger companies have a higher debt capacity and easy access to sources of finance caused by less volatile cash flows and diversified business (lower information asymmetry). Market to book has a negative relationship with 
target leverage (-0.00941, p-value less than 0.001). Highly market valued companies prefer internal funds or more probably equity issuance. Reducing leverage is logical in periods of favourable market conditions (high equity market value). This result is consistent with market timing (Baker and Wurgler, 2002). Along with market to book, total return (average annual stock return) is a proxy for growth and is negatively correlated to target debt ratio $(-6.25 \mathrm{e}-05$, $\mathrm{p}$-value less than 0.001). An increase in stock prices, according to financing hierarchy, leads to equity issuance. A negative correlation between leverage and growth confirms the assumptions of market timing theory (managers are reluctant to issue equity when it is under-priced). The regression estimates show a statistically significant and negative correlation between profitability and target leverage ratio $(-0.0759, \mathrm{p}$-value less than 0.001$)$. Highly profitable companies are cash-rich firms which prefer the hierarchy in financing, exploiting retained earnings and internal sources. As for product uniqueness, the regression coefficient of -0.0875 (p-value less than 0.001 ) demonstrates that unique production and high $R \& D$ expenses are mostly related to high growth and profitable companies. Highly levered companies are not able to finance these activities.

The difference when compared to previous studies is only found in relation between tangibility and target leverage (-0.0143, p-value less than 0.001$)$. The main explanation for this result can be found in the period covering the analysis, the sixth M\&A cycle 2003-2010, which included the global financial crisis. The crisis and post crisis-period were characterized by higher interest rates and tightened credit markets. Moreover, as stated by Lauk (2014), the European Central Bank stimulated short-term funding in the last decade. Companies were largely issuing Commercial Papers (short-term debt), refinancing long-term with short-term debt. Refinancing may happen especially in periods when companies expect a deterioration of cash flows over time (just before and after the crisis). Changing the debt maturity structure is an efficient tool of decreasing the cost of debt and increasing shareholder value. During the recovery period, the growth of the economy is anticipated and stock prices are expected to rise (Drobetz et al., 2007). Therefore, companies are motivated to time the market and issue equity (decreasing leverage),specifically, large and faster growing companies as acquirers, adjust rapidly and have higher financial flexibility in recovery periods. Additionally, from 2000 onwards, classical collateral is no longer sufficient - expected cash flow trends and balance sheet strength became crucially important as collateral (Sherman, 2010). The majority of acquisition from the sample were performed by highly profitable companies. 
Finally, the heterogeneity of economic development across the countries of Western Europe (e.g. the UK, Germany, and France, compared to Italy, Spain) represents an important factor of capital structure decisions. Capital structure choices are made differently in each country, depending on the level of progress in capital market development, availability of financing sources, corporate governance, legal environment etc. (Xie et al., 2017). European evidence showed that institutional and regulatory framework impact on capital structure policy and decisions over debt issuance (Bancel and Mittoo, 2004). Koralun-Bereźnicka (2017) argues that capital structure in Europe considerably depends on the country in which the company operates, also highlighting the importance of company size and specific industry factors. In line with these results, De Jong et al. (2008) confirmed the importance of firm-specific and country-specific factors as factors of leverage, on a sample of firms on a global level. Kirch et al. (2012) concluded that firm-specific characteristics represent the main factor in the process of capital structure selection. All of these arguments can be a potential cause of tangibility coefficient's negative sign.

\subsection{Estimation of probability of making an acquisition depending on leverage deficit - univariate and multivariate analysis}

In the second phase, the leverage deficit variable is used in an estimation of the likelihood of making an acquisition. Leverage deficit is defined as the actual leverage ratio minus the estimated target leverage. If the actual leverage ratio is higher than estimated, the company is considered to be overleveraged. However, if actual leverage ratio is lower than estimated, the company is defined as underleveraged. More precisely, firms in the first (fourth) quartile have the lowest (largest) leverage deficit and are defined as underleveraged (overleveraged). Table 3 summarizes leverage deficit descriptive statistics.

Even though the mean value of leverage deficit equals zero (on average, actual leverage is equal to target leverage), the large standard deviation of $18.6 \%$ implies that the sample consists in companies whose debt deviates from target debt ratio. More precisely, $25 \%$ of companies are underleveraged by less than $-11.2 \%(\mathrm{Q} 1)$, whilst other, $25 \%$ of companies from the sample, are overleveraged by more than $9.8 \%(\mathrm{Q} 3)$. Accordingly, companies tend to change and adjust capital structure in the process of corporate restructuring (acquisitions). These changes are evident in the figure below. 
Table 3

Leverage deficit descriptive statistics

\begin{tabular}{l|c}
\hline \multicolumn{1}{c|}{ Value } & Leverage deficit \\
\hline Mean & $9.19 \mathrm{e}-12$ \\
\hline Median & 0.00062 \\
\hline Standard deviation & 0.186 \\
\hline Variance & 0.034 \\
\hline Range & 3.731 \\
\hline Min & -0.540 \\
\hline Max & 3.190 \\
\hline Coefficient of variation & $2.02 \mathrm{e}+10$ \\
\hline Q1 & -0.112 \\
\hline Q3 & 0.098 \\
\hline Interquartile range & 0.210 \\
\hline
\end{tabular}

Source: author's calculations.

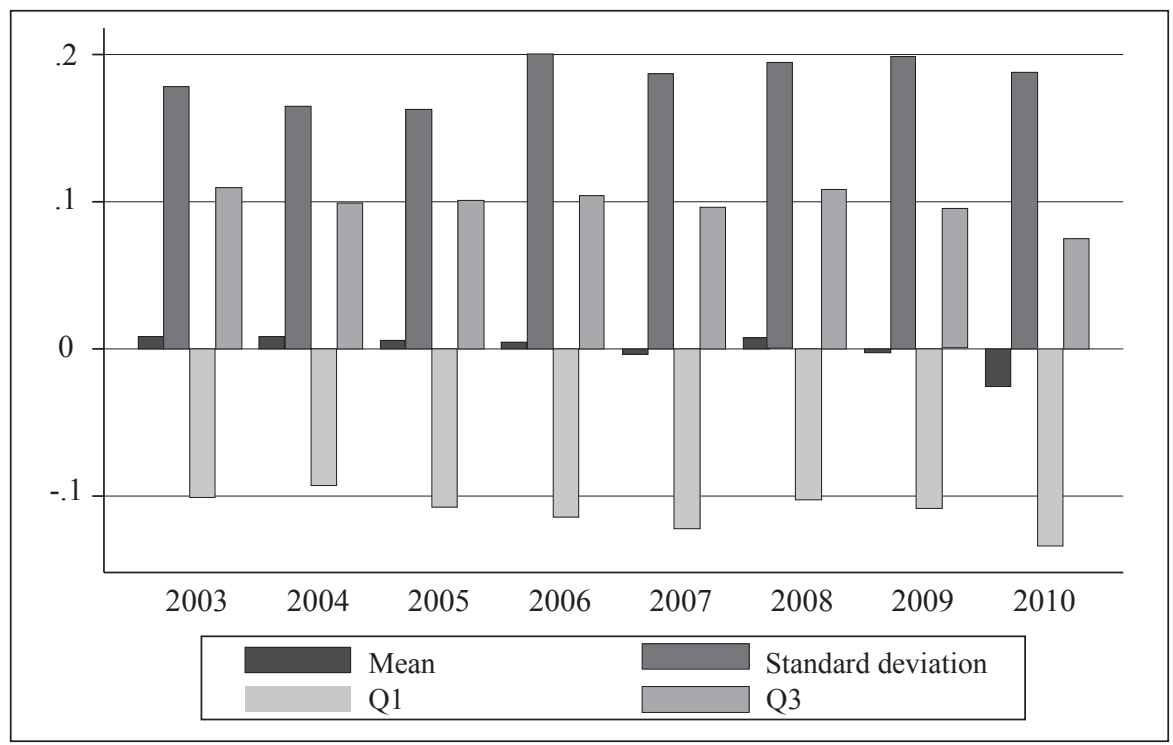

Fig. 1. Leverage deficit mean, standard deviation, Q1 and Q3

Source: author's own.

Deviations (Q1 and Q3) are present in the whole period of analysis, yet, from 2005, deviations are larger in Q1 (underleveraged group). The mean value of leverage deficit was negative during 2007, 2009 and 2010. It is obvious that large acquirers from the sample have rebalanced their capital 
structure prior to acquisition announcements. Furthermore, in 2007 financial markets' credit activity was tightened, which additionally impacted on the level of leverage.

In line with the probability analysis, it is worth applying both probability analyses, univariate and multivariate. Univariate demonstrates companies' characteristics by leverage deficit quartiles (by quartiles companies are divided in two groups: underleveraged and overleveraged). The results are shown in Table 4. As quartiles are quantiles that divide data series in four equal categories, the mean values of variables are given in four categories of book

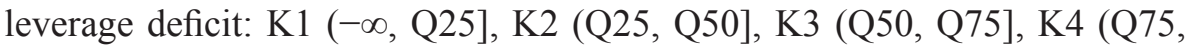
$+\infty)$. Testing the statistical difference of means was performed applying multivariate tests: Wilks' lambda, Pillai's trace, the Lawley-Hotelling trace, and Roy's largest root. The results confirm that the mean differences from K1$\mathrm{K} 4$ are statistically significant at the $1 \%$ level, except for the total return.

Table 4

Firm characteristics by book leverage deficit quartiles

\begin{tabular}{l|c|c|c|c}
\hline \multicolumn{5}{c}{ Leverage deficit quartiles } \\
\hline \multicolumn{1}{c|}{ Variables } & K1 & K2 & K3 & K4 \\
\hline Book leverage & 0.375 & 0.543 & 0.649 & 0.801 \\
\hline Tangibility & 0.772 & 0.740 & 0.747 & 0.769 \\
\hline Market to book & 1.670 & 1.385 & 1.279 & 1.378 \\
\hline Logarithm of sales & 9.192 & 9.303 & 9.304 & 9.211 \\
\hline Profitability & 0.167 & 0.148 & 0.131 & 0.135 \\
\hline Product uniqueness & 0.024 & 0.021 & 0.016 & 0.0192 \\
\hline Total return & 24.897 & 29.069 & 25.204 & 27.011 \\
\hline
\end{tabular}

Source: author's calculations.

Comparing the variables from $\mathrm{K} 1$ to $\mathrm{K} 4$, it can be concluded that companies from $\mathrm{K} 1$ are performing better: lower leverage, higher market to book (growth), higher R\&D expenses (by $0.5 \%$ on average) and higher profitability (by $3 \%$ on average). Tangibility and sales values are similar across the categories. On the other hand, the better performance of overleveraged companies is found in the capital market (the return is $2 \%$ higher in K4 on average). Even though mean values may potentially imply the higher probability of underleveraged companies to undertake an acquisition, these values do not always change monotonically by leverage deficit categories. This is why multivariate analysis (probit) was applied. In order to contribute to the objectivity of the results, two models using probit methodology were tested. 
To obtain more precise results, probit model tested the marginal effects of variables (Uysal, 2007, 2011). The marginal effects of continuous variables were computed at the sample means of the data, while the marginal effects of binary variables as the difference between cumulative distribution functions for discrete changes of dummy variables in interval from 0 to 1 . The probability of acquisition is related to the success of the undertaken acquisitions. In the case of a successful transaction, the dependent variable takes value 1, and in the case of an unsuccessful transaction, the dependent variable takes value 0 . The explanatory variables included in the model are leverage deficit, size, growth and profitability. Previously conducted studies (Datta et al., 2001; Officer,2003; Moeller et al., 2004) showed that big companies have a welldiversified business portfolio, stable cash flows and easy access to sources of financing. Furthermore, acquisition value depends on the acquirer's and target's growth perspective (Smith and Kim, 1994). Finally, financial-slack rich bidders will create higher acquisition worth, specifically when acquiring financial slack-poor targets. The model is defined by:

$$
P(\text { acquistion }=1)=\phi\left(\beta_{0}+\beta_{1} \text { leverage deficit }+\beta_{1} Z_{i}\right),
$$

where: $Z_{i}$ is vector of explanatory variables and, a $\phi$ is cumulative normal distribution function. In order to capture more precisely the effect of leverage deficit, this variable is transformed in dummy variable underleveraged companies, taking the value of 1 for Q1 leverage deficit values, and 0 for all other values. Therefore, the other model is defined as follows:

$$
P(\text { acquistion }=1)=\phi\left(\beta_{0}+\beta_{1} \text { underleveraged companies }+\beta_{1} Z_{i}\right),
$$

where: $Z_{i}$ is vector of explanatory variables and, a $\phi$ is cumulative normal distribution function. The results of the probabilities of both models are given in the following table.

The first hypothesis is confirmed: the results prove the higher probability of acquisition for the subgroup of underleveraged companies. According to Model 1, the increase of variable underleveraged companies increases the probability of acquisition by $5.42 \%$. A statistically significant and positive relation was found between size, profitability and acquisition probability. It could be concluded that in the region of Western Europe, more success in acquisition process is had by larger and more profitable companies. The variables, growth and average return, have a positive sign but there is no evidence on the statistically significant impact on acquisition probability. 
Table 5

Probability of undertaking an acquisition depending on leverage deficit

\begin{tabular}{l|c|c}
\hline \multicolumn{1}{c|}{ Variable } & Model 1 & Model 2 \\
\hline Underleveraged companies & $\begin{array}{c}0.0542^{* * *} \\
(0.00905)\end{array}$ & 0.00639 \\
\hline Market to book (growth) & 0.00390 & $(0.00507)$ \\
\hline Sales (size) & $(0.00450)$ & $0.0119^{*}$ \\
\hline Profitability & $0.0113^{*}$ & $(0.00650)$ \\
\hline Total return (growth) & $(0.00655)$ & $0.170^{* * *}$ \\
\hline Leverage deficit & $0.154^{* * *}$ & $(0.0595)$ \\
\hline Number of observations & $(0.0578)$ & $2.96 \mathrm{e}-05$ \\
\hline Pseudo $\mathrm{R}^{2}$ & $3.86 \mathrm{e}-05$ & $(7.06 \mathrm{e}-05)$ \\
\hline Prob $>\chi^{2}$ & $(7.08 \mathrm{e}-05)$ & $-0.0248^{* * *}$ \\
\hline
\end{tabular}

Notes: Standard errors in parentheses $/ * * * \mathrm{p}<0.01, * * \mathrm{p}<0.05, * \mathrm{p}<0.1$

Source: author's calculations.

A strong negative relation between leverage deficit and acquisition probability was found in Model 2. The increase in leverage deficit by one standard deviation decreases the probability of acquisition by $2.48 \%$, i.e. companies with higher target debt ratios (overleveraged) are less likely to make an acquisition. The coefficients sign and statistical significance of explanatory variables is the same as in Model 1.

\subsection{Estimation of the effects of acquisition announcements on capital markets - CAR estimation}

The aim of this research stage was to assess the market reaction to the acquisition announcements, measured by bidders' cumulative abnormal returns. The results of the test answer if there exists a statistically significant relation between CAR and leverage deficit, and if confirmed, is it negative or positive. The test was conducted by applying an event study and consisted of several steps:

- defining the number of observations: 2028, as several bidders undertook more than one acquisition; 
- estimation window was defined in intervals of 250 to 50 days $[-250,-50]$ before the announcement date of acquisitions. The companies without a sufficient number of observations were excluded, and the final number of transactions amounted to 1564 ;

- the expected return of each stock was calculated based on the market model. The benchmark return was the value-weighted index of returns including dividends for the index BE500;

- abnormal returns of stocks were calculated as the difference between actual and expected returns;

- in the five-day event window, two days before and two days after the announcement date [-2,2], average abnormal returns and CARs were calculated;

- the statistical significance of CARs was confirmed;

- CARs were regressed over leverage deficit.

The relation between capital structure and CARs was estimated with ordinary least square methodology and defined with the following regression equation (Model 1):

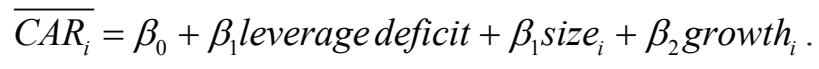

Estimation of Model 1 generated statistically insignificant results, which was the reason to formulate Model 2. In Model 2 variable growth was excluded:

$$
\overline{C A R_{i}}=\beta_{0}+\beta_{1} \text { leveragedeficit }+\beta_{1} \text { size }_{i} .
$$

The results of both models are given in Table 6 .

Table 6

Impact of leverage deficit on CARs

\begin{tabular}{l|c|c}
\hline \multicolumn{1}{c|}{ Variable } & Model 1 & Model 2 \\
\hline \multirow{2}{*}{ Leverage deficit } & 0.00333 & $0.00591^{* *}$ \\
& $(0.00309)$ & $(0.00302)$ \\
\hline \multirow{2}{*}{ Size } & $-6.63 \mathrm{e}-11$ & $-2.68 \mathrm{e}-10$ \\
& $(3.14 \mathrm{e}-10)$ & $(3.08 \mathrm{e}-10)$ \\
\hline \multirow{2}{*}{ Growth } & $1.09 \mathrm{e}-09$ & \\
\hline \multirow{2}{*}{ Constant } & $(1.25 \mathrm{e}-09)$ & 0.00162 \\
\hline $\mathrm{R}^{2}$ & 0.00254 & $(0.00327)$ \\
\hline
\end{tabular}

Notes: Standard errors in parentheses/ $* * * \mathrm{p}<0.01 * * \mathrm{p}<0.05 * \mathrm{p}<0.1$

Source: author's calculations. 
Model 2 gave statistically significant results of the leverage deficit coefficient. The Link and Ramsey Reset test confirmed that Model 2 was well specified. One can conclude that the leverage deficit is positively correlated with CARs - an increase of leverage deficit by $1 \%$ increases CARs by $0.591 \%$ $(p<0.05)$. Thus this increase implies that only overleveraged companies undertake the most value-enhancing acquisitions. The value of $0.3 \% \mathrm{R}^{2}$ is low, but confirmed in previous research (on average $4 \%$ ). The low value of $\mathrm{R}^{2}$ can be justified by the lack of data related to the characteristics of transactions which were included in the previous studies. (Moeller et al., 2004; Masulis et al., 2007).

Accordingly, the second research hypothesis result is: the market reaction is negative to announcements of underleveraged bidders. The results are consistent with the free cash flow hypothesis (Jensen, 1986), meaning CARs are decreasing when cash-rich bidders are announcing acquisitions, and that capital markets react unfavourably to takeover announcements of underleveraged bidders (Maloney et al., 1993; Uysal, 2007, 2011; Durand et al., 2016; Beschwitz, 2018).

\section{CONCLUSION}

Capital structure adjustments represent a very important factor of the investment decision-making process and company value creation. This paper analysed the impact of deviations from target debt ratio on acquisition choices and market reaction on announcements of these transactions. As noted in the paper, all the results are consistent with previous research focused on the relation between leverage and corporate restructuring.

Target debt ratio was regressed on the main determinants widely used: tangibility, growth, size, profitability, product uniqueness and average stock return. The results showed a statistically significant and negative relation of target leverage and each variable, except size. A negative relation between leverage and tangibility is the only result which differs from previous research results. The justification is found in macroeconomic conditions during the period of analysis (the period of the sixth M\&A cycle of 2003-2010, which included global financial crises), specific factors of a country in which the company is doing business (the sample is heterogenic - from the UK and Germany, to Italy and Spain), financial market conditions and trends, heterogeneity of companies in the sample, structure of debt (the high proportion of short-term debt leads to a negative relation of leverage and tangibility). Additional arguments were given by Drobetz et al. (2007) in the context of anticipated economy growth in the process of recovery after crisis. The growth 
motivates companies to issue shares, as their prices are expected to rise. The research confirmed that especially large and fast growing companies (like bidders for companies from the sample) rapidly adjust their capital structure in the recovery period, as these companies are profitable and the majority accumulated internal sources of financing.

In the second stage, the probability of making an acquisition was tested by univariate and multivariate (probit) analysis. Both analyses gave the same result: underleveraged companies are more likely to undertake the acquisition. The analysis of two models using probit methodology contributed to the objectivity of the results. Model 1 showed that an increase of dummy variable unleveraged companies by one standard deviation increased the probability of acquisition by $5.42 \%$, while Model 2 tested the probability depending on leverage deficit, and the results showed that an increase of leverage deficit by one standard deviation decreased the probability of acquisition by $2.48 \%$. An increase of leverage deficit is a positive deviation from target debt ratio (overleveraged companies), which confirms that underleveraged companies have a higher probability to engage in acquisitions.

In the final stage, the test of CARs indicated that the market reacts unfavourably to acquisition announcements of underleveraged companies, which is consistent with Jensen's free cash flow hypothesis. If leverage deficit increases by $1 \%$, CARs will increase by $0.591 \%$. Consequently this increase implies that only overleveraged companies undertake the most valueenhancing acquisitions and that underleveraged companies make poor acquisition choices.

A negative market reaction is confirmed in various papers analysing markets globally. Yet, only Uysal $(2007,2011)$ applied the concept of leverage deficit in the context of acquisition decisions in the US market. This research contributes to the analysis of the leverage deficit concept, as capital structure shaping represents an actual scientific dilemma not widely researched in Western Europe. The empirical verification of the model could be beneficial for managers in the process of evidence-based capital structure decisionmaking. This paper provides the findings on the most important factors of optimal capital structure, as well as on the impact of this structure on future investment decisions. Finally, the research opens up the possibility to compare findings and test differences between the EU and US capital markets.

The continuous changes of capital structure in the global market (high leverage) imply the necessity of a deeper analysis of M\&A financing and the success of these transaction. In that sense, future research should focus on the effects of leverage deficit on other investment strategies and corporate decisions. Additionally, attention should be given to the development of new 
capital structure models, which will be broadened by new explanatory variables, such as production costs, corporate management and control etc. In this way the analysis of corporate decisions could be enhanced and upgraded.

\section{REFERENCES}

Ahmed, Y., Elshandidy, T., Why Do Over-Deviated Firms from Target Leverage Undertake Foreign Acquisitions?, "International Business Review", Vol. 27, No 2, pp. 309-327, 2018.

Andrade, G., Mitchell, M., Stafford, E., New Evidence and Perspectives on Mergers, "Journal of Economic Perspectives“, Vol.15, No 2, pp. 103-120, 2001.

Baker, H. K., Martin, G. S., Capital Structure and Corporate Financing Decisions. The Robert W. Kolb Series in Finance. John Wiley \& Sons, Inc., Hoboken, New Jersey, 2011.

Baker, M., Wurgler, J., Market Timing and Capital Structure, "Journal of Finance“, Vol. 57, No 1, pp. 1-32, 2002.

Bancel, F., Mittoo, U., Cross-Country Determinants of Capital Structure Choice: A Survey of European Firms, "Financial Management", Vol. 33, No 4, pp. 103-132, 2004.

Baltagi, B. H., Econometric Analysis of Panel Data. John Wiley \& Sons, 2013.

Beschwitz, B., Cash windfalls and acquisitions, "Journal of Financial Economics", Vol. 128, No 2, pp. 287-319, 2018.

Bouraoui, T., Li, T., The Impact of Adjustment in Capital Structure in Mergers \& Acquisitions on US Acquirers Business Performance, "Journal of Applied Business Research", Vol. 30, No 1, pp. 27-42, 2014.

Brounen, D., Jong, A., Koedijk, K., Capital Structure Policies in Europe: Survey Evidence, "Journal of Banking and Finance", Vol. 30, No 5, pp. 1409-1442, 2006.

Chang, X, Dasgupta, S., Monte Carlo Simulations and Capital Structure Research, "International Review of Finance“, Vol.11, No 1, pp. 19-55, 2011.

Datta, S., Datta, M., Raman, K., Executive compensation and corporate acquisition decisions, "Journal of Finance", Vol. 56, No 6, pp. 2299-2336, 2001.

De Jong, A., Kabir, R., Nguyen, T., Capital structure around the world: The roles of firmand country-specific determinants, "Journal of Banking and Finance", Vol. 32, No 9, pp. 1954-1969, 2008.

Drobetz, W., Pensa, P., Wanzenried, G., Firm Characteristics, Economic Conditions and Capital Structure Adjustments. Working Paper No. 16/07, pp. 1-38, Centre of Business and Economics (WWZ), University of Basel, 2007.

Durand, R. B., Laing, E., Thao Ngo, M., The disciplinary role of leverage: evidence from East Asian cross-border acquirers' returns, "Finance Research Letter", Vol. 18, C, pp. 83-88, 2016.

Eckbo, B. E., Bidding Strategies and Takeover Premiums: A Review, "Journal of Corporate Finance“, Vol. 15, No 1, pp. 149-178, 2009.

Fama, E., Fisher, F., Jensen, L. M., Roll, R., The Adjustment of Stock Prices to New Information, "International Economic Review", Vol. 10, No 1, pp. 1-21, 1969.

Fama, E., French, K. R., Testing Trade-off and Pecking-Order Predictions about Dividends and Debt, "Review of Financial Studies", Vol. 15, No 1, pp. 1-33, 2002.

Flannery, M., Rangan, K., Partial adjustment towards target capital structures, "Journal of Financial Economics“, Vol. 79, No 3, pp. 469-506, 2006. 
Frank, M. Z, Goyal, V. K., Capital Structure Decisions: Which factors are Reliably Important, "Financial Management", Vol. 38, No 1, pp. 1-37, 2009.

Graham, J. R., Harvey, C. R., The theory and practice of corporate finance: Evidence from the field, "Journal of Financial Economics", Vol.60, No 2, pp. 187-243, 2001.

Harford, J., Corporate Cash Reserves and Acquisitions, "The Journal of Finance“, Vol. 54, No 6, pp. 1969-1997, 1999.

Harford, J., Klasa, S., Walcott, N., Do Firms Have Leverage Targets? Evidence from Acquisitions, "Journal of Financial Economics", Vol. 93, No 1, pp. 1-14, 2009.

Harford, J., Uysal, V. B., Bond market access and investment, "Journal of Financial Economics", Vol. 112, No 2, pp. 147-163, 2014.

Hernádi, P., Ormos, M., Capital Structure and Its Choice in Central and Eastern Europe, "Acta Oeconomica“, Vol. 62, No 2, pp. 229-263, 2012.

Hovakimian, A., Opler, T., Titman, S., The Debt-Equity Choice, "Journal of Financial and Quantitative Analysis“, Vol. 36, No 1, pp. 1-24, 2001.

$\mathrm{Hu}, \mathrm{M}$., Yang, J., The role of leverage in cross-border mergers and acquisitions, "International Review of Economics \& Finance“", Vol. 43, C, pp. 170-199, 2016.

Jensen, M., Agency Cost of Free Cash Flows, Corporate Finance and Takeover, "American Economic Review“, Vol. 76, No 2, pp. 323-329, 1986.

Kayhan, A., Titman, S., Firms Histories and Their Capital Structure, "Journal of Financial Economics“, Vol. 83, No 1, pp. 1-32, 2007.

Kang, J. K., The international market for corporate control: Mergers and acquisitions of U.S. firms by Japanese firms, "Journal of Financial Economics", Vol. 34, No 3, pp. 345-371, 1993.

Kędzior, M., Capital structure in EU selected countries - Micro and macro determinants, "Argumenta Oeconomica", Vol. 28, No 1, pp. 69-117, 2012.

Kirch, G., Mateus, C, Terra, P., Country Governance Structure and Financial Development as Determinants of Firms' Capital Structure, "Journal of Money, Investment and Banking", Issue 26, pp. 6-24, 2012.

Koralun-Bereźnicka, J., How Does the Firm Size Affect the Relative Importance of Country and Industry Effect in Capital Structure? Empirical Evidence from Europe, "Argumenta Oeconomica", Vol. 38, No 1, pp. 99-119, 2017.

Lauk, C. T., The Triple Crisis of Western Capitalism: Democracy, Banking, and Currency. Palgrave Macmillan, 2014.

Leary, M. T., Roberts, M. R., Do Firms Rebalance Their Capital Structures?, "Journal of Finance“", Vol. 60, No 6, pp. 2575-2619, 2005.

Lemmon, M. L., Roberts, M. R., Zender, J. F., Back to the beginning: persistence and the crosssection of corporate capital structure, "Journal of Finance“, Vol. 63, No 4, pp. 1575-1608, 2008.

Maloney, M. T., McCormick, R. E., Mitchell, M. L., Managerial Decision Making and Capital Structure, "Journal of Business", Vol. 66, No 2, pp. 189-217, 1993.

Martynova, M., Renneboog, L. D. R., What determines the financing decision in corporate takeovers: Cost of capital, agency problems, or the means of payment?, "Journal of Corporate Finance“, Vol. 15, No 3,pp. 290-315, 2009.

Masulis, R. W., Wang, C., Xie, F., Corporate Governance and Acquirer Returns, "Journal of Finance“, Vol. 62, No 4, pp. 1851-1889, 2007. 
Modigliani, F., Miller, H. M., The Cost of Capital, Corporation Finance and the Theory of Investment, "American Economic Review“", Vol. 48, No 3, pp. 261-297, 1958.

Moeller, S. B., Schlingemann, F. P., Stulz, R., Firm size and the gains from acquisitions, "Journal of Financial Economics", Vol. 73, No 2, pp. 201-228, 2004.

Mugoša. A., The determinants of capital structure choice: Evidence from Western Europe, "Business and Economic Horizons", Vol. 11, No 2, pp. 76-95, 2015.

Myers, S. C., The Capital Structure Puzzle, "The Journal of Finance“, Vol. 39, No 3, pp. 575-592, 1984.

Officer, M., Termination fees in mergers and acquisitions, "Journal of Financial Economics", Vol. 69, No 3, pp. 431-67, 2003.

Parsons, C., Titman, S., Empirical Capital Structure: A Review, "Foundations and Trends in Finance“, Vol. 3, No 1, pp. 1-93, 2009.

Rajan, G. R., Zingales, L., What Do We Know about Capital Structure? Some Evidence from International Data, "Journal of Finance", Vol. 50, No 5, pp. 1421-1460, 1995.

Smith, R. L., Kim, J., The combined effects of free cash flow and financial slack on bidder and target stock returns, "Journal of Business", Vol. 67, No 2, pp. 281-310, 1994.

Sherman, A. J., Mergers and acquisitions from A to Z. American Management Association, New York 2010.

Tao, Q., Sun, W., Zhu, Y., Zhang, T., Do firms have leverage targets? New evidence from mergers and acquisitions in China, "The North American Journal of Economics and Finance“, Vol. 40, pp. 41-54, 2017.

Titman, S., Wessels, R., The Determinants of Capital Structure Choice, "Journal of Finance“, Vol.43, No 1, pp. 1-19, 1988.

Uysal, V. B., Deviation from Target Capital Structure and Acquisition Choices, University of Oklahoma and AFA Meeting Conference paper, 2007.

Uysal, V. B., Deviation from Target Capital Structure and Acquisition Choices, "Journal of Financial Economics“, Vol. 102, No 3, pp. 602-620, 2011.

Vermaelen, T., Xu, M., Acquisition finance and market timing. "Journal of Corporate Finance", Vol. 25, pp. 73-91, 2014.

Welch, I., Capital Structure and Stock Returns, "Journal of Political Economy“, Vol. 112, No 1, pp. 106-131, 2004.

Wooldridge, J. M., Introductory Econometrics: A Modern approach. South-Western, Cengage Learning, 2012.

Xie, E., Reddy, K. S., Liang, J., Country-specific determinants of cross-border mergers and acquisitions: A comprehensive review and future research directions, "Journal of World Business", Vol. 52, No 2, pp. 127-183, 2017.

Yang, T., The Adjustment of Capital Structure in Mergers and Acquisitions: Re-visit the Theory of Optimal Capital Structure, Working paper, 2011. http://citeseerx.ist.psu.edu/viewdoc/ summary?doi=10.1.1.557.477

Received: July 2019, revised: May 2020 